\title{
Organic Dairy Farming as a Tool to Ensure stainable Rural Livelihood - A Grassroot Perspective
}

\author{
Madhu Shelly* \\ Assistant Professor in Animal Science, Punjab Agricultural University, India
}

Submission: July 26, 2018; Published: August 08, 2018

*Corresponding author: Madhu Shelly, Assistant Professor (Animal Science), Krishi Vigyan Kendra, Muktsar, Punjab Agricultural University, Ludhiana, Punjab, Email: gsmadhu786@gmail.com

\begin{abstract}
Organic milk can help avoid risk of cardiovascular disease, cancer, depression, rheumatoid arthritis and diabetes like health problems associated with modern lifestyle. The increasing awareness among consumers about health benefits of organic milk and the increased purchasing power of new generation have increased the prospects of organic dairy production. Organic livestock production requires that animals are fed organic feed, have access to pasture or outside with restricted use of antibiotics and hormones. Organic feed is produced without the use of synthetic fertilizers or pesticides for at least three years prior to harvest. Some feed additives such as vitamins, minerals and probiotics can be added to feed if they are approved by a certifying organic authority. A proper herd health program should include strategies for disease prevention, parasitic control and disease treatment. All vaccines for endemic disease are approved. Herbal, naturopathic and homeopathic treatments are approved for use on organic animals. Producers of organic animal products need to maintain full records (which can be checked by a certifying authority at any time) and must only market healthy animals and animal products.

Changing to organic dairy production requires commitment and awareness of what's involved. Becoming organic can lower cost of production for grassroot people (smallholder dairy farmers) while at the same time raise their profits. However financial returns shall depend greatly on the demand generated. Due to rich heritage of dairy farming traditions suitable for organic production systems with good returns, India is in a unique position to utilize this opportunity. However, for this purpose, several policy issues require immediate attention. Creating awareness among farmers and their training through dairy field functionaries, capacity building through participatory research network and incentives for interested farmers (like subsidized inputs and supply of market information) shall be the priorities. Therefore, the following study was conducted to judge awareness of dairy farmers about organic milk production and their concerns about transition to organic dairy farming.
\end{abstract}

Keywords: Organic dairy production; Health benefits; Grass root people; Awareness; Capacity building; Organic feed; Livestock; Pasteurization; Linoleic acid; Calcium, Magnesium, Phosphorus; Iron; Fertilizers

\section{Introduction}

Organic dairy farming means raising animals on organic feed (i.e. pastures cultivated without the use of fertilizers or pesticides), have access to pasture or outside along with the restricted usage of antibiotics and hormones [1]. Also, milk should be piped from the udders to the chilling and pasteurization units directly by automated systems. This ensures no hand contact that might lead to contamination.

Organic dairy farming offers a plethora of health benefits for livestock and humans. This results in a positive impact on environment, benefitting the community. It therefore involves the integration of animal-pasture-crop production to yield wholesome milk and milk products free from ill effects of pesticides, fertilizers and hormones. A recent research has pointed out that organic milk contains 62 percent more omega- 3 fats than conventional milk and it has less of the damaging omega- 6 fats. A higher omega- 3 to omega- 6 ratio is required in body to avoid health problems like cardiovascular diseases, cancer, depression and Alzheimer's, rheumatoid arthritis and diabetes. The organic milk also contains greater amounts of conjugated linoleic acid (CLA), a cancer fighting fatty acid. CLA also helps boost the immune system and reduce the growth of tumours.

Other benefits associated with organic milk (website of organic facts) are its rich antioxidant properties (due to lutein and zeaxanthin), protection against macular degeneration and cataracts, its ability to aid in reduction of abdominal fat, cholesterol and allergic reactions and boosting metabolism in body. Since cow's graze on grass in natural pastures, therefore organic milk acquires many nutrients, including vitamin E, beta carotene and the healthy fats (omega - 3 and CLA). Moreover, feeding a grass silage-based diet supplemented with commodity concentrates has a definite economic advantage for dairy producers under organic system of production [2].

High quality organic raw milk is loaded with healthy bacteria good for digestive system, more than 55 different digestive enzymes, growth factors and immunoglobulins, amino acids 
and proteins in highly bio available forms (also 100 percent digestible), rich in vitamins (A, B, C, D, E and $\mathrm{K}$ ) in highly bio available forms and a very balanced blend of minerals (calcium, magnesium, phosphorus and iron) whose absorption is enhanced by live lactobacilli. In fact, this nutrient composition fights everything from allergies to digestive problems to eczema. Somatic cell count is significantly lower in organic milk (79455 $+53101)$ as compared to conventional milk $(90152+50097)$ reported by Francia et al. [3].

The excessive use of the chemicals and hormones in conventional milk production and the harmful effects that they create, have resulted in an increased demand for organic milk from health-conscious consumers. Organic dairy does not allow the use of any slaughter by-products, urea, manure or genetically modified organisms (GMOs) [4]. In addition, organic dairy farming promotes animal as well as consumer welfare. Certain procedures like tail docking are not allowed. Dehorning must be done to minimize stress on the animals. The farmer claiming his dairy products to be organic must keep enough records to verify his compliance with the standards. Moreover, each farm must be inspected and audited each year, and this can be done unannounced at any time.

The organic dairy market however is hard to cultivate and maintain. And maintaining organic farmland and ensuring wholly Results and Discussion organic feed for the cattle is an expensive proposition given the low awareness coupled with low demand for this milk. The cost of production on conventional dairy farm is close to zero with the man looking after fields and wife cares for the cows. And the feed for the cows comes from the leftover parts of the crops grown in the fields. Also, the consumer in India will take time to adjust with the new taste and increased cost.

The present study was conducted with the twin objectives of:

i. Judging the awareness of dairy farmers about organic dairy farming practices and;

ii. to evaluate the prospects of organic dairy farming in India with its package of opportunities and threats.

\section{Materials and Methods}

A small sample size of twenty farmers was randomly chosen from five villages of Muktsar district in Punjab. The herd size with these farmers varied from 5-40 animals. The number of animals in milk was approximately 30 percent in all the herds. The awareness of farmers was judges through a structured questionnaire. Further their views regarding the present market structure for organic milk and its popularisation was also evaluated. Data was analysed using simple frequency and percentage method.

Table 1: Awareness level about organic dairy farming parameters among farmers.

\begin{tabular}{|c|c|c|c|}
\hline Sr. No. & Parameter of organic dairy farming & $\begin{array}{l}\text { No. of farmers } \\
\text { aware }\end{array}$ & $\begin{array}{l}\text { Percentage of } \\
\text { farmers aware }\end{array}$ \\
\hline 1 & $\begin{array}{l}\text { Crop and pasture land are to be managed without the use of synthetic fertilizers, fungicides, } \\
\text { herbicides, GMOs or insecticides for } 3 \text { consecutive years }\end{array}$ & 2 & 10 \\
\hline 2 & Organic dairy certification is required from a reputed body & 10 & 50 \\
\hline 3 & $\begin{array}{c}\text { Complete organic certification requires a farm to be operated as organic for full one year. This is } \\
\text { transition time and is mandatory in addition to earlier } 3 \text { years }\end{array}$ & 2 & 10 \\
\hline 4 & $\begin{array}{c}\text { Feeding } 100 \text { percent organic and balanced rations to cows and replacement heifers with exceptions } \\
\text { of minerals and other essential ingredients that cannot be sourced as organic }\end{array}$ & 6 & 30 \\
\hline 5 & $\begin{array}{c}\text { Avoiding use of antibiotics or synthetic hormones-under supervision of a vet antibiotic use is } \\
\text { permitted twice a year per cow but withdrawal period must be extended }\end{array}$ & 8 & 40 \\
\hline 6 & Providing a comprehensive history of all land to be certified & 2 & 10 \\
\hline 7 & $\begin{array}{l}\text { Providing access to certified organic grazing land throughout the growing season. Pasture must } \\
\text { provide at least } 30 \text { percent of the total dry matter intake }\end{array}$ & 3 & 15 \\
\hline 8 & $\begin{array}{l}\text { Housing should be clean, dry, sufficient space with comfortable bedding to minimise stress. Animals } \\
\text { should have access to outside throughout the year }\end{array}$ & 4 & 20 \\
\hline
\end{tabular}

Organic dairy farming as a general concept is taken as an eco-friendly venture wherein there is no usage of hormones or antibiotics in animals to increase milk production. However, there are many associated conditions and parameters to be met for organic dairy enterprise. A perusal of Table 1 shows quite low awareness level among farmers for different parameters (for a dairy to be certified as organic). Although 50 percent knew that a certificate from a government body is mandatory for a product to be labelled as organic, the time involved was known only to 10 percent farmers. It was also noticed that those farmers who regularly visited dairy exhibitions and attended seminars were more aware as compared to others.

A study of Table 2 reveals numerous concerns among farmers regarding lack of guidance and marketing of organic dairy products. However, India does have some inherent contributing factors to organic movement which can help us take advantage of the opportunities involved: -

a. India has rich heritage of farming traditions that are suitable to design organic production systems capable of yielding returns comparable to conventional farming and in some cases even better. 
b. Some resource poor farmers in remote rainfed areas of the country are practicing organic farming by default.

c. Organic dairy products have big and growing market potential, so a developing country like India can get high export earnings in international market provided proper quality control Table 2: Concern among farmers for switching over to organic dairy farming

\begin{tabular}{|c|c|c|c|}
\hline Sr. No. & Parameter of organic dairy farming & No. of farmers & Percentage of farmers \\
\hline 1 & Lack of proper guidance and training facilities & 18 & 90 \\
\hline 2 & $\begin{array}{l}\text { Consumer demand for organic dairy products as there was low consumer } \\
\text { awareness also }\end{array}$ & 16 & 80 \\
\hline 3 & Increased cost of dairy operations & 12 & 60 \\
\hline 4 & Marketing of costly organic dairy products & 14 & 70 \\
\hline 5 & Lack of government support & 15 & 75 \\
\hline
\end{tabular}

And there are certain steps which shall require our immediate attention:

a. Creating awareness through trained extension functionaries.

b. Development of protocols for organic production through farmers participatory network research.

c. Capacity building of different stakeholders on different aspects of organic production and,

d. Development of preferential policy instruments for interested farmers particularly in terms of providing market information and subsidized supply of inputs.

To realize the full potential of organic dairy farming, a number of researches, development and policy issues need to be addressed. This calls for a clear-cut strategy for redefining priorities, channelizing the investment in research and development of organic dairy products with field demonstrations to validate scientific findings, joint effort of producers, processors, traders and streamlining the supply and distribution chains for organic agripreneurship. This shall help India in achieving the three main objectives of sustainable farming: environmental health, economic profitability and socio-economic equity. is maintained during production and processing.

d. Demand for organic products and consequently the ensuing profits do fluctuate but growing health concerns among the new generation coupled with increased purchasing power can provide the required buffer for producers.

\section{Conclusion}

Organic dairy farming offers numerous opportunities for a developing country like India to increase the income of farmers and earn valuable foreign exchange through quality organic products. Government policies should provide support by linking farmers with domestic as well as export markets and by providing minimum support prices to their products. The process of organic certification needs to be clearly defined (with adjustments for local requirements wherever possible) and made simpler so as to reach many small and marginal farmers in the country.

\section{References}

1. Oruganti Madhuri (2011) Organic dairy farming- a new trend in dairy sector. Veterinary World 4(3): 128-130.

2. Marston SP, Clark GW, Anderson GW, Kersbergen RJ, Lunak M, et al. (2011) Maximizing profit on New England dairy farms: an economic comparison of 4 total mixed rations for organic Holsteins and jerseys. J Dairy Sci 94(6): 3184-3201.

3. Di Francia A, Masucci F, De Rosa G, Grasso F, Proto V (2007) Feeding management and milk production in organic and conventional buffalo farms. Ital J Anim Sci 6(2): 571-574.

4. Health benefits of organic milk. 